SJ Quinney College of Law, University of Utah

Utah Law Digital Commons

$12-2020$

Will China's New Anti-Suit Injunctions Shift the Balance of Global FRAND Litigation?

Jorge L. Contreras

Follow this and additional works at: https://dc.law.utah.edu/scholarship

Part of the Intellectual Property Law Commons 


\title{
Will China’s New Anti-Suit Injunctions Shift the Balance of Global FRAND Litigation?
}

\author{
Yang Yu and Jorge L. Contreras*
}

\begin{abstract}
By issuing anti-suit injunctions (ASIs) in Conversant v. Huawei and InterDigital v. Xiaomi, Chinese courts have signaled a new willingness to vie for jurisdictional authority in global battles over standard-essential patents and FRAND licensing. While the Supreme People's Court in Conversant largely followed the pattern of US and UK courts that have issued ASIs in similar cases, the ruling of the Wuhan court in InterDigital is far broader in two major respects. First, its geographic scope is not limited to the country in which InterDigital sought injunctive relief (India), but extends to all jurisdictions in the world. Second, it prohibits InterDigital from seeking a determination of a global FRAND rate for its $3 G / 4 G$ patents anywhere in the world. In view of these two recent cases, China has clearly joined the international race to be the jurisdiction of choice for determining FRAND royalty rates in global disputes involving standard-essential patents.
\end{abstract}

As one of us has recently observed, ${ }^{1}$ courts in the U.S. and UK adjudicating cases involving standards-essential patents and FRAND licensing commitments ${ }^{2}$ have increasingly issued injunctions preventing one party from pursuing parallel litigation in another jurisdiction (anti-suit injunctions or ASIs). In response, courts in other countries - namely Germany and France - have begun to issue anti-anti-suit injunctions (AASIs) to prevent parties from seeking ASIs that would hinder their own proceedings. And even anti-anti-anti suit injunctions (AAASIs) have emerged as more than theoretical possibilities. Amidst this international jockeying for jurisdiction, commentators have wondered where it will end, and whether every country involved in complex, multi-jurisdictional disputes will get into the ASI game. In two recent cases, China has now stepped forward as another major jurisdiction in which ASIs are available to litigants.

\footnotetext{
${ }^{*} \mathrm{Yu}$ is an Associate Professor at Shanghai University of International Business and Economics. Contreras is a Presidential Scholar and Professor of Law at the University of Utah S.J. Quinney College of Law.

${ }^{1}$ See Jorge L. Contreras, It's Anti-Suit Injunctions All The Way Down-The Strange New Realities of International Litigation Over Standards-Essential Patents, IP LiTigATOR, 26(4):1-7 (July/ Aug. 2020), [hereinafter Contreras, AntiSuit Injunctions], https://papers.ssrn.com/sol3/papers.cfm?abstract_id=3647587; see also Jorge L. Contreras, The New Extraterritoriality: FRAND Royalties, Anti-Suit Injunctions and the Global Race To The Bottom in Disputes Over Standards-Essential Patents, 25 BU SCI. \& TECH. L.J. 251 (2019) [hereinafter Contreras, Extraterritoriality].

${ }^{2}$ A FRAND commitment is an obligation undertaken by a participant in a standards development organization (SDO) to grant licenses of its patents that are essential to implementation of one of the SDO's standards on terms that are fair, reasonable and nondiscriminatory. For a primer on standards development and FRAND commitments, see Jorge L. Contreras, Technical Standards: Fair, Reasonable, and Non-Discriminatory (FRAND) Licensing, in INTELLECTUAL Property Licensing AND TRANSACtions: TheORY AND PRActice, Chapter 2 (2020, forthcoming), https://papers.ssrn.com/sol3/papers.cfm?abstract_id=3669316.
} 


\section{Conversant v. Huawei ${ }^{3}$}

The first case involves Chinese smartphone manufacturer Huawei and Texas-based patent assertion entity Conversant Wireless Licensing (formerly Core Wireless). Conversant holds a globe-spanning portfolio of patents that it acquired from Nokia and which it claims are essential to the $2 \mathrm{G}, 3 \mathrm{G}$ and $4 \mathrm{G}$ wireless telecommunications standards developed under the auspices of the European Telecommunications Standards Institute (ETSI). Conversant sought to license these patents to Huawei, but negotiations broke down and in 2017 and in 2018 Conversant asserted the patents against Huawei in multiple jurisdictions. The UK suit was recently decided by the UK Supreme Court ${ }^{4}$ which held that a UK court has the authority to set a global FRAND royalty rate between the parties, notwithstanding its lack of jurisdiction over patents outside the UK. ${ }^{5}$ (This case also involved an unsuccessful 2018 bid by Conversant to obtain an ASI from the UK Court of Chancery ${ }^{6}$ against the prosecution of a related suit by ZTE, Huawei's co-defendant, in the Shenzhen Intermediate People's Court in $\mathrm{China}^{7}$ ).

In response to Conversant's initial patent assertions, in January 2018 Huawei sought declarations from the Nanjing Intermediate People's Court of Jiangsu Province, China, that it did not infringe three of Conversant's Chinese patents and, if it did, that it was entitled to a license on FRAND terms. On September 16, 2019, the Nanjing court declined to issue a declaration regarding infringement, but established a "top down" FRAND royalty for the three Conversant patents. ${ }^{8}$ The decision is currently on appeal at the Supreme People's Court (SPC) of China.

Meanwhile, in April 2018, Conversant sued Huawei in the District Court in Düsseldorf, Germany, alleging infringement of several European patents. On August 27, 2020, the Düsseldorf court granted Conversant an injunction against Huawei's sale, use or importation in Germany of devices infringing patent EP1797659 (the German Patent).

On the same day, Huawei applied to the SPC seeking an "act preservation" ruling (a judicial action roughly equivalent to an ASI) to prevent Conversant from enforcing the Düsseldorf injunction until the conclusion of the Chinese proceedings. The SPC granted the ASI after an ex parte hearing in which Conversant did not participate. In its decision, the SPC cited a number of factors weighing in favor of granting the ASI, many of which resemble the factors considered by U.S. courts when considering ASIs: ${ }^{9}$

\footnotetext{
${ }^{3}$ An unofficial translation of the decision by $\mathrm{Yu}$ is available at https://patentlyo.com/media/2020/10/Huawei-V.Conversant-judgment-translated-10-17-2020.pdf.

${ }^{4}$ Unwired Planet International Ltd v. Huawei Technologies (UK) Co Ltd [2020] UKSC 37 (appeal taken from EWCA).

${ }^{5}$ See Jorge L. Contreras, The UK Supreme Court's Re-interpretation of FRAND in Unwired Planet v. Huawei, PATENTLYO (Aug. 27, 2020), https://patentlyo.com/patent/2020/08/supreme-interpretation-unwired.html.

${ }^{6}$ Conversant Wireless Licensing S.A.R.L. v. Huawei Technologies Co. Ltd. [2018] EWHC (Ch) 2549.

${ }^{7}$ See Contreras, Extraterritoriality, supra note 2.

${ }^{8}$ See Jacob Schindler, Nanjing Judge Sets Chinese SEP Rate in Dispute Between Conversant and Huawei, IAM (Sep. 23, 2019), https://www.iam-media.com/frandseps/nanjing-judge-sets-chinese-sep-rate-in-dispute-betweenconversant-and-huawei; see also Alexandra P. Yang, Inside China's First Top-Down FRAND Royalty Decision, IAM (Aug. 5, 2020), https://www.iam-media.com/frandseps/inside-chinas-first-top-down-frand-royalty-decision.

${ }^{9}$ See Contreras, Extraterritoriality, supra note 2, at 265-67.
} 
- the parties to the Chinese and German actions are the same;

- there is partial overlap between the subject matter of the cases;

- Conversant's enforcement of the German injunction would interfere with the Chinese action;

- in order to avoid the effects of the German injunction, Huawei must either withdraw from the German market or accept the license offered by Conversant in Germany, which sets a global FRAND royalty rate that is 18.3 times higher than the rate set by the Nanjing court;

- imposition of the ASI will not materially prejudice Conversant's rights in Germany with respect to the merits decisions (as opposed to the injunction decisions) of the German courts;

- imposition of the ASI will not harm the public interest;

- imposition of the ASI will not affect international comity, as the Chinese actions were brought before the German action and the ASI will not affect the subsequent trial in the German case or detract from the legal validity of the German judgment.

Also relevant to the SPC's decision, though not specifically included in its consideration of the ASI, was the fact that in August, 2018, the Chinese State Intellectual Property Office (SIPO) ruled that the Chinese counterpart to the German Patent was invalid. Conversant brought an administrative lawsuit challenging that ruling in the Beijing Intellectual Property Court. That matter is still pending.

Upon entry of the ASI, the SPC established a penalty of RMB 1 million per day (approximately US $\$ 150,000$ ) if Conversant violates the ASI. Because the ASI was issued ex parte, Conversant was entitled to apply for reconsideration within five days. It did so, and its request was denied on September 11, leaving the ASI in force.

\section{Interdigital v. Xiaomi ${ }^{10}$}

The dispute between InterDigital, a U.S.-based patent assertion entity, and Xiaomi, a Beijing-based electronics firm, relates to five InterDigital patents covering the $3 \mathrm{G}$ and $4 \mathrm{G}$ standards. When negotiations for a license failed, on June 9, 2020 Xiaomi sought a declaration by the Wuhan Intermediate People's Court of the appropriate FRAND royalty rate for the patents. On July 29, InterDigital sued Xiaomi for infringement in the Delhi High Court in India, seeking monetary damages and an injunction. In response, on August 4, Xiaomi asked the Wuhan court for an "act preservation" ruling (ASI) preventing InterDigital from enforcing the injunction while the Wuhan proceeding was in progress.

The Wuhan court granted Xiaomi's request, reasoning that:

- InterDigital's filing of parallel litigation in India during the pendency of the Wuhan case showed a lack of respect for the Wuhan court and the case before it;

- The Indian action was intended to interfere with and obstruct the Wuhan case;

- The Indian action is likely to lead to a ruling in conflict with that of the Wuhan court;

- The entry of an injunction in India will likely cause significant harm to Xiaomi;

- Because InterDigital is a non-practicing entity that does not make products, but relies solely

${ }^{10}$ An unofficial translation of the decision by $\mathrm{Yu}$ is available at https://patentlyo.com/media/2020/10/Xiaomi-v.InterDigital-decision-trans-10-17-2020.pdf. 
on licensing income, it would not be harmed substantially by the inability to seek an injunction against Xiaomi

Accordingly, on September 23, the Wuhan court (a) ordered InterDigital to withdraw its requests for injunctive relief in India, (b) prohibited InterDigital from seeking injunctive relief in China or any other country with respect to the $3 \mathrm{G} / 4 \mathrm{G}$ patents currently at issue in the Wuhan case, and (c) prohibited InterDigital from asking another court in China or any other country to determine a FRAND royalty rate or resolve a FRAND dispute relating to the $3 \mathrm{G} / 4 \mathrm{G}$ patents at issue.

As in Conversant v. Huawei, the Wuhan court established a penalty of RMB 1 million per day (approximately US\$150,000) if InterDigital violates the ASI. Because the ASI was issued ex parte, InterDigital was entitled to apply for reconsideration within five days. It did so, and its request appears to have been denied, leaving the ASI in force.

In response to the entry of the ASI by the Wuhan court, InterDigital disclosed to the U.S. Securities and Exchange Commission ${ }^{11}$ that on September 29, it filed for an anti-anti-suit injunction (AASI) in the Delhi High Court to prevent Xiaomi from enforcing its Chinese ASI. The Delhi High Court granted the AASI on October 9. ${ }^{12}$ This is the first instance of which we are aware of an AASI being sought in a FRAND case in India (prior examples being observed in Germany, France and the $\mathrm{UK}) .{ }^{13}$

\section{Discussion}

The ASIs issued by Chinese courts in Conversant v. Huawei and InterDigital v. Xiaomi signal a new willingness of Chinese courts to vie for jurisdictional authority in global battles over standardessential patents. To some degree, this development was entirely predictable. Courts in the U.S. and UK have, for several years, sought to resolve global FRAND disputes being litigated on the international stage. But there is no reason that U.S. and UK courts should be the exclusive venues for such proceedings. The courts of every country in which the parties have sufficient assets to care about adverse rulings can exert similar authority. As one of us has previously observed, ${ }^{14}$ this inter-jurisdictional competition is rapidly leading to a "race to the bottom" and a "race to the courthouse" in international FRAND disputes.

Yet even more seems to be at play in these two cases than China's adoption of jurisdictional measures already deployed in the U.S. and UK. The ruling of the Wuhan court is far broader than the Supreme People's Court's ruling in Conversant v. Huawei in two major respects that are worth

\footnotetext{
11 See SEC, Interdigital, Inc. (Sep. 23, 2020), https://d18rn0p25nwr6d.cloudfront.net/CIK-0001405495/0b31e2595609-44a2-973c-f9a7bc1768a4.html; see also Richard Lloyd, InterDigital Asks Delhi Court for Anti-anti-suit Injunction in Licensing Fight With Xiaomi, IAM, https:/www.iam-media.com/frandseps/interdigital-asks-delhicourt-anti-anti-suit-injunction-in-fight-xiaomi.

${ }^{12}$ Interdigital Tech. Corp. v. Xiaomi Corp., High Court of Delhi, I.A. 8772/2020 in CS(COMM) 295/2020 (Oct. 9, 2020). See also Rajiv Choudhry, Delhi High Court Issues Anti Anti-Suit Injunction in InterDigital v. Xiaomi Patent Infringement Dispute, SPICYIP, Oct. 12, 2020, https:/spicyip.com/2020/10/delhi-high-court-issues-anti-anti-suitinjunction-in-interdigital-v-xiaomi.html.

${ }^{13}$ See Contreras, Anti-Suit Injunctions, supra note 2.

${ }^{14}$ See Contreras, Extraterritoriality, supra note 2.
} 
considering. First, its geographic scope is not limited to the country in which InterDigital sought injunctive relief (India), but extends to all jurisdictions in the world. As an anti-suit measure, this is more sweeping than any ASI issued in U.S. or other courts in FRAND cases. Under U.S. and UK law, a court considering a request for an ASI must compare the action in the domestic court with the parallel action in the foreign court and determine whether they address the same matter and whether the resolution of the domestic action would dispose of the foreign action. This type of analysis is not possible with an ASI that is not directed to a particular foreign action, but prospectively prohibits any attempt to seek an injunction anywhere in the world.

The second major addition by the Wuhan court is the prohibition on InterDigital's ability to ask any other court in the world to determine a global FRAND rate for its $3 \mathrm{G} / 4 \mathrm{G}$ patents. As such, China has clearly joined the international race to be the jurisdiction of choice for determining FRAND royalty rates in global disputes involving standard-essential patents. 